\title{
Antilisterial activity of dromedary lactoferrin peptic hydrolysates
}

\author{
Zeineb Jrad, ${ }^{1}$ Halima El-Hatmi, ${ }^{1,2 *}$ Isabelle Adt, ${ }^{3}$ Sandrine Gouin, ${ }^{3}$ Julien Jardin, ${ }^{4}$ Olfa Oussaief, ${ }^{1}$ \\ Mohamed Dbara, ${ }^{1}$ Samira Arroum, ${ }^{1}$ Touhami Khorchani, ${ }^{1}$ Pascal Degraeve, ${ }^{3}$ and Nadia Oulahal ${ }^{3}$ \\ ${ }^{1}$ Livestock and Wildlife Laboratory, Arid Land Institute, 4119, Medenine, Tunisia \\ ${ }^{2}$ Food Department, Higher Institute of Applied Biology of Médenine, University of Gabes, 4119, Medenine, Tunisia \\ ${ }^{3}$ University of Claude Bernard Lyon 1, ISARA Lyon, BioDyMIA (Bioingénierie et Dynamique Microbienne aux Interfaces Alimentaires), \\ Equipe Mixte d'Accueil no. 3733, IUT Lyon 1, 01000 Bourg en Bresse, France \\ ${ }^{4}$ STLO, UMR1253, INRA, AgroCampus Ouest, 35000 Rennes, France
}

\section{ABSTRACT}

The aim of this study was to explore the antibacterial peptides derived from dromedary lactoferrin $(\mathrm{LFc})$. The LFc was purified from colostrum using a batch procedure with a cation exchange chromatography support and was hydrolyzed with pepsin to generate peptic digest. This peptic digest was fractionated by cation exchange chromatography, and the antilisterial activity of LFc, peptic digest, and obtained fractions was investigated using the bioscreen method. The growth of Listeria innocua ATCC 33090 and LRGIA 01 strains was not inhibited by LFc and its hydrolysates. Two fractions of dromedary lactoferrin peptic hydrolysate were active against both strains. A tandem mass spectroscopy analysis revealed that the 2 active fractions comprised at least 227 different peptides. Among these peptides, 9 found in the first fraction had at least $50 \%$ similarity with 10 known antimicrobial peptides (following sequence alignments with the antimicrobial peptide database from the University of Nebraska Medical Center, Omaha). Whereas 9 of these peptides presented homology with honeybee, frog, or amphibian peptides, the 10th peptide, $F_{152}$ SASCVPCVDGKEYPNLCQLCAGTGENKCACSSQEPYFGY $_{192}$ (specifically found in 1 separated fraction), exibited $54 \%$ homology with a synthetic antibacterial peptide (AP00481) derived from human lactoferrin named kaliocin-1. Similarly, the second fraction contained 1 peptide similar to lactoferrampin $\mathrm{B}$, an antibacterial peptide derived from bovine milk. This result suggests that peptic hydrolysis of LFc releases more active antimicrobial peptides than their protein source and thus provides an opportunity for their potential use to improve food safety by inhibiting undesirable and spoilage bacteria.

Received August 13, 2018.

Accepted February 25, 2019.

*Corresponding author: halima.elhatmi@ira.rnrt.tn
Key words: dromedary lactoferrin, pepsin hydrolysis, antibacterial activity, lactoferrin-derived peptide

\section{INTRODUCTION}

Milk proteins have attracted interest in the field of healthy food because they are the most important source of bioactive peptides (Mohanty et al., 2016). Among these proteins, lactoferrin ( $\mathbf{L F}$ ) is a bilobal glycoprotein that belongs to the transferrin family, which is found in tears, saliva, milk, and colostrum (van der Strate et al., 2001). The highest levels of LF production are attributed to dromedary colostrum $(1.4-5 \mathrm{~g} / \mathrm{L}$ on the second day after parturition; El-Hatmi et al., 2007), whereas its concentration in bovine colostrum was only about 0.5 to $1 \mathrm{~g} / \mathrm{L}$ in the study of Konuspayeva et al. (2007). The dromedary and bovine LF are polypeptide chain that respectively include 689 and 700 AA residues that share 74.9 and $91.6 \%$ sequence identity and similarity, respectively (Kappeler et al., 1999).

Even if LF is a multifunctional protein and currently recognized as a nutraceutical compound, data on dromedary LF activities are scarce. Few reports have led us to the study of antimicrobial (Conesa et al., 2008; Ismael et al., 2013; Redwan et al., 2016), anticancer, and antioxidant (Habib et al., 2013) activities of dromedary LF. However, many authors have studied bovine $\mathrm{LF}$ and reported that it is strongly involved in many biological processes, such as antioxidant (Kruzel et al., 2013), anticancer (Tsuda et al., 2010), immunomodulatory (Wen et al., 2017), and anti-inflammatory (Zucca et al., 2017) activities. Recently, prevention of osteoporosis (Shi et al., 2018; Zhang et al., 2018) and regulation of metabolic disorders such as obesity, diabetes, and cardiovascular diseases have been ascribed to bovine LF (Iglesias-Figueroa et al., 2019). Moreover, bovine LF is mainly recognized as an antimicrobial protein; it inhibits bacterial growth by sequestering surrounding iron (Velliyagounder et al., 2003) or destabilizing gram-negative bacterial membrane via interacting with bacterial LPS (Jenssen and Hancock, 2009). 
Interestingly, the hydrolysis of bovine LF by pepsin results in the liberation of antimicrobial fragments that exert a higher antimicrobial activity than the entire molecule (Tomita et al., 1991; Bellamy et al., 1992). The identified antibacterial fragments from bovine LF are N-terminal zone fragments. The amino termini of bovine and dromedary LF (LF f 1-59) contain 14 and 13 basic residues, respectively, with a high content of Arg and Lys, making them strongly cationic like numerous antimicrobial peptides (AMP; i.e., lactoferricin; Bellamy et al., 1992). However, to the best of our knowledge, no study has dealt with the AMP derived from dromedary milk LF (LFc). Bovine LF and its derived peptides display a significant in vitro inhibitory effect on selected pathogens such as Escherichia coli, Staphylococcus aureus, Pseudomonas aeruginosa, and Listeria monocytogenes (Ripolles et al., 2015; IglesiasFigueroa et al., 2019).

The strain L. monocytogenes causes listeriosis, which is the most important source of food diseases that are associated with consumption of food contaminated by Listeria (Aygun and Pehlivanlar, 2006). Listeria spp. can survive and multiply in a large variety of food matrices, such as raw milk, soft cheese, raw vegetables, fruits, and food industry environments, which poses serious public health risks and economic loss. Because Listeria innocua and L. monocytogenes are closely related species as shown by phylogenetic analysis, and taking into account that $L$. innocua is nonpathogenic, it is possible to use this strain in an attempt to predict $L$. monocytogenes response behavior (den Bakker et al., 2010). Furthermore, different physical and chemical treatments have been widely studied to control $L$. monocytogenes and L. innocua contamination in food (Morandi et al., 2009; Bernini et al., 2015). However, physical treatment needs high capital investment, and the use of chemical preservatives in food products cannot be considered safe. Therefore, food contamination with Listeria spp. can be controlled by safe AMP derived from natural sources such as dromedary LF. As previously reported, dromedary colostrum exhibits inhibitory effects against Listeria species growth, and antilisterial activity is still present after enzymatic hydrolysis (Benkerroum et al., 2004; Jrad et al., 2014). Thus, we did not know whether dromedary LF is responsible for the antilisterial activity of dromedary colostrum.

The purposes of this study were (1) to evaluate in vitro the antimicrobial activity of colostrum, LF, and its peptic hydrolysate against an industrial dairy-isolated strain of L. innocua in addition to the American Type Culture Collection (ATCC) strain and (2) to investigate the ability of the dromedary LF to generate potent antibacterial peptides that can be applied in the control of Listeria spp. growth. In this study, we considered the nonpathogenic L. innocua species because it can be isolated from different types of dairy products and it is physiologically very similar to the pathogenic $L$. monocytogenes (Hammer et al., 2017).

\section{MATERIALS AND METHODS}

\section{Preparation of Dromedary Colostrum Whey Proteins}

Colostrum samples were collected from 8 multiparous healthy dromedaries (Camelus dromedarius) belonging to the experimental farm of the Livestock and Wildlife Laboratory (Arid Land Institute of Medenin, Tunisia). Dromedaries were manually milked the second and third days after parturition.

Dromedary colostrum whey proteins was prepared according to the method described by Jrad et al. (2014). Fresh dromedary colostrum was centrifuged $(5,000 \times g$ for $30 \mathrm{~min}$ at $4^{\circ} \mathrm{C}$ ) to remove fat, and caseins were eliminated by acid precipitation at $\mathrm{pH} 4.2$ with a $1 \mathrm{M}$ acetic acid solution followed by a centrifugation step $\left(5,000 \times g\right.$ for 30 min at $\left.20^{\circ} \mathrm{C}\right)$. The $\mathrm{pH}$ of the obtained supernatant (containing dromedary whey proteins) was adjusted to $\mathrm{pH} 7$ with $1 \mathrm{M} \mathrm{NaOH}$ and dialyzed against ultrapure water (Milli-Q equipment; Millipore, Bedford, MA) for $72 \mathrm{~h}$ to remove salts, peptides, and proteins with a lower molecular weight than LF (20-kDa cutoff cellulose dialysis membrane; SpectraPor, Spectrum Labs Inc., Milpitas, CA). Colostrum whey was then kept at $-20^{\circ} \mathrm{C}$ before being used for LF purification (an aliquot was freeze-dried for further analysis).

\section{Dromedary LF Purification}

Lactoferrin purification was performed with a cation exchange chromatography (CEC) support using a batch procedure adapted from El-Hatmi et al. (2006). First, 5 volumes of dromedary colostral whey protein solution was mixed with 1 volume of CM Sepharose Fast Flow gel (GE Healthcare Life Sciences, VélizyVillacoublay, France), stirred for $4 \mathrm{~h}$ under slight agitation, and filtered through a glass membrane. Then, the CM Sepharose Fast Flow gel was suspended again in 5 volumes of sodium phosphate buffer $(50 \mathrm{mM}$, pH 7.2) and mixed for $2 \mathrm{~h}$ under slight agitation. Thereafter, the mixing, stirring, and filtering procedure was repeated using sodium phosphate buffer with $0.2 \mathrm{M}$ added sodium chloride. Aliquots $(100 \mu \mathrm{L})$ from each filtrate (successively named filtrates 1, 2, and 3) were stored for further analysis. Thereafter, LF fraction was eluted by mixing 5 volumes of the same sodium phosphate buffer added to sodium chloride $(0.6 M)$ for $3 \mathrm{~h}$. At that point, the filtrate containing dromedary LF (filtrate 4) was dialyzed (with a 100- to 500-Da cut- 
off dialysis membrane) against Milli-Q water for $3 \mathrm{~d}$ to remove salts, lyophilized, and stored at $-20^{\circ} \mathrm{C}$ until further analysis. Sepharose gel was then regenerated by mixing overnight with 5 volumes of sodium phosphate buffer (50 mM, pH 7.2) with $1 M$ added sodium chloride and filtered through a glass filter membrane; 100 $\mu \mathrm{L}$ of the resultant filtrate (filtrate 5 ) was sampled out for analysis. Finally, dromedary LF was recovered by lyophilization of filtrates 4 and 5 .

\section{Iron Saturation of Dromedary LF Analysis}

The iron saturation of dromedary LF was determined according to the method described by Zhang et al. (2018) with some modifications. The iron concentration of LFc was determined by atomic absorption spectrophotometry (Shimadzu AA-6800, Shimadzu, Duisburg, Germany). Then, iron saturation was determined as follows:

$$
\text { IS }(\%)=\frac{C}{1.49} \times 100 \text {, }
$$

where IS is the iron saturation of sample (\%); C is the iron concentration of LFc; and 1.49 is the correction factor, which was calculated as follows:

$$
\mathrm{CF}=\frac{\mathrm{MWI} \times \mathrm{nFI}}{\mathrm{MMLFc}},
$$

where CF is the correction factor; MWI is the molecular weight of iron; nFI is the number of molecules of ferric iron; and MMLFc is the molecular mass of LFc.

\section{In Vitro Peptic Digestion}

The in vitro enzymatic hydrolysis procedure of purified dromedary LF by pepsin was adapted from Murdock and Matthews (2002) and Plate et al. (2006). Aqueous solutions of LF (50 g/L) were adjusted to $\mathrm{pH}$ 2 by dropwise addition of hydrochloric acid ( $\mathrm{HCl} ; 2 M)$. Pepsin (from porcine stomach mucosa; Sigma-Aldrich, Saint-Quentin Fallavier, France; activity $=3,000-4,500$ units/mg; EC 2.32.629.3) was then added (enzyme: substrate ratio $3 \% \mathrm{wt} / \mathrm{wt}$ in final volume) before incubation at $37^{\circ} \mathrm{C}$ for $4 \mathrm{~h}$. The enzymatic hydrolysis experiment was stopped by dropwise addition of $\mathrm{NaOH}$ $(2 M)$ to adjust $\mathrm{pH}$ to 7 followed by heating at $80^{\circ} \mathrm{C}$ for 5 min before centrifugation at $15,000 \times g$ for 20 $\min \left(4^{\circ} \mathrm{C}\right)$. Supernatant was recovered and stored at $-20^{\circ} \mathrm{C}$ until further analysis. Control without pepsin was prepared under the same conditions to determine the effect of temperature and $\mathrm{pH}$ on dromedary LF. We performed SDS-PAGE and reversed-phase (RP)HPLC analyses of peptic hydrolysates and control (nonhydrolyzed dromedary LF) to assess hydrolysis of LF and the liberation of peptide fragments of LF, respectively. Primary amines were also assayed using the 2,4,6-trinitrobenzenesulfonic acid (TNBS) method to estimate the degree of hydrolysis (DH) of LFc as described thereafter.

\section{Free Amino Groups Assays by TNBS Method}

We calculated the LF DH following pepsin action using free amino group's determination by TNBS method adapted from McKellar (1981). Nonhydrolyzed, hydrolyzed LF, and standard (Leu solutions) samples were dissolved in a sodium bicarbonate solution $(0.1 \mathrm{M}, \mathrm{pH}$ 8.5) to obtain a $500-\mu \mathrm{L}$ final volume and mixed with $250 \mu \mathrm{L}$ of TNBS $(0.1 \mathrm{~g} / \mathrm{L})$ reagent. After $2 \mathrm{~h}$ of incubation in the dark at $37^{\circ} \mathrm{C}, 250 \mu \mathrm{L}$ of $\operatorname{SDS}(10 \mathrm{~g} / \mathrm{L})$ and $125 \mu \mathrm{L}$ of hydrochloric acid $(1 M)$ were added before measurement of absorbance at $420 \mathrm{~nm}$. All reagents were purchased from Sigma-Aldrich.

The $\mathrm{DH}$ was defined as the ratio between the number of nanomoles of free amine groups following peptic hydrolysis and the theoretical number of free amine groups released if native LF would be totally hydrolyzed in free AA (both expressed in nanomoles equivalent Leu).

\section{LF Hydrolysates Fractionation by CEC}

Peptic hydrolysates of dromedary LF were fractionated by CEC using a procedure adapted from Chan and Li-Chan (2007). Briefly, peptides generated from LF were separated by CEC using a C106EP/2156 resin provided by Purolite (Paris, France) using a sodium phosphate buffer $(50 \mathrm{mM}, \mathrm{pH} 6.5)$ supplemented with increasing $\mathrm{NaCl}$ concentrations (from 0 to $2 M$ ) as eluent to perform a 6 -step gradient. Fractions were collected and pooled considering their absorbance at 280 $\mathrm{nm}$ and the ionic force used in their elution. Pooled fractions were dialyzed (with 100- to 500-Da cut-off membranes; SpectraPor, Spectrum Labs Inc.) against Milli-Q water (Millipore) for 72 to $120 \mathrm{~h}$ to remove salts that could interfere with the antibacterial activity assays. Dialysates were then freeze-dried and stored at $-20^{\circ} \mathrm{C}$ until further analysis.

\section{SDS-PAGE Analysis}

To check the purification of dromedary LF, an SDSPAGE of filtrates 1 to 5 and colostrum was performed as described by Laemmli (1970) using a 7.5\% T sepa- 
rating gel and a Protean II xi Cell system (Bio-Rad, Marnes La Coquette, France) at $140 \mathrm{~V}$ for $1 \mathrm{~h} 30 \mathrm{~min}$.

\section{Bacterial Strains and Culture Conditions}

Antibacterial activity assays were performed against 2 strains of L. innocua: an ATCC strain (L. innocua ATCC 33090) and an industrial dairy-isolated strain (L. innocua LRGIA 01; Mariani et al., 2007). Stock cultures were maintained at $-20^{\circ} \mathrm{C}$ in tryptone soy broth (TSB; Biokar Diagnostics, Beauvais, France) supplemented with $15 \%$ (vol/vol) glycerol. Before each test, the 2 target strains were subcultured in TSB at $10 \%$ (vol/vol) for $8 \mathrm{~h}$ at $30^{\circ} \mathrm{C}$ and then precultured in TSB at $10 \%$ (vol/vol) for $12 \mathrm{~h}$ at $30^{\circ} \mathrm{C}$. Finally, the last culture was transferred in $50 \mathrm{~mL}$ of fresh brain-heart infusion (BHI) broth (Biokar Diagnostics) and incubated for $6 \mathrm{~h}$ at $30^{\circ} \mathrm{C}$ to obtain bacteria in exponential growth phase for antilisterial activity assays.

\section{Antilisterial Activity Assays}

Freeze-dried samples of dromedary colostral whey as well as hydrolyzed or nonhydrolyzed dromedary LF and fractions pooled after the CEC separation of peptic hydrolysates were resuspended at a concentration of 0.5 or $1 \mathrm{mg} / \mathrm{mL}$ in BHI broth.The antimicrobial activity assays were performed in 100-well microtiter plates. In each well, $30 \mu \mathrm{L}$ of bacterial culture was mixed with 270 $\mu \mathrm{L}$ of sample dissolved in BHI broth (all tested samples were sterilized by filtration onto $0.2-\mu \mathrm{m}$ membranes). Final bacterial concentration by well was around 1 $\times 10^{5} \mathrm{cfu} / \mathrm{mL}$. For each run, both positive (bacterial growth in BHI broth without any sample) and negative (wells containing 2,400 IU/mL nisin) controls were also monitored.

The optical density at $600 \mathrm{~nm}\left(\mathrm{OD}_{600}\right)$ was recorded every 15 min using a Bioscreen $\mathrm{C}$ plate reader (Thermo Fisher, Illkirch, France) at $30^{\circ} \mathrm{C}$ for $24 \mathrm{~h}$. The percentage reduction of $\mathrm{OD}_{600}$ after 24 -h incubation was determined using the formula

$\%$ reduction $=$

$\frac{\mathrm{OD}_{600} \text { in positive control well }-\mathrm{OD}_{600} \text { in test well }}{\mathrm{OD}_{600} \text { in positive control }} \times 100$.

Each antimicrobial activity assay was performed in triplicate (3 wells/plate). As all cultures were performed in triplicate, a $t$-test (2 samples, assuming unequal variances) was run to compare bacterial growth curves in media with or without testing sample. The differences were considered significant when $P<0.05$ and when calculated inhibition percentage exceeded $10 \%$.

\section{Nano-Electrospray lonization Tandem MS Coupled with Liquid Chromatography}

Fractionated LF hydrolysates were analyzed by online nano-electrospray ionization tandem MS coupled with liquid chromatography after reduction of disulphur bonds by addition of dithotreitol $(50 \mathrm{mM})$ in ammonium hydrogen carbonate buffer $(\mathrm{pH} 8)$ and incubation at room temperature for $2 \mathrm{~h}$. Samples (10 $\mu \mathrm{L}$ ) were loaded on a nanoLC DionexRSLC system coupled to a Thermo Scientific Q Exactive QuadrupoleOrbitrap mass spectrometer (Dionex/Thermo Scientific, Villebon-sur-Yvette, France) after a concentration step on an RP-HPLC $\mathrm{C}_{18}$ PepMap 100 (5 mm, $100 \AA$; 300- $\mu \mathrm{m}$ i.d., 5-mm length) cartridge. Chromatographic separation was performed on an RP-HPLC $\mathrm{C}_{18}$ Acclaim PepMap100 column (150-mm length, 75- $\mu$ m i.d., $3-\mu \mathrm{m}$ particle size, $10-\mathrm{nm}$ porosity; Dionex/Thermo Scientific) with a linear gradient from 5 to $35 \%$ (vol/ $\mathrm{vol}$ ) acetonitrile in water in the presence of $0.08 \%$ (vol/ vol) formic acid and $0.1 \%$ (vol/vol) trifluoroacetic acid for $35 \mathrm{~min}$ at a flow rate of $0.3 \mu \mathrm{L} / \mathrm{min}$. Ionization of peptides by a Proxeon electrospray ionization source was performed in positive mode at a voltage of $2 \mathrm{kV}$ as previously described (Jrad et al., 2014). Peptides were identified from MS/MS spectra using X!Tandem pipeline software (Langella et al., 2017). The peptide identification database comprised the Camelus dromedarus taxonomy (no. 9838; downloaded from http:// www.uniprot.org; July 2014).

Sequence alignments with known AMP were performed with the AMP database (http://aps.unmc.edu/ $\mathrm{AP} /$ database/query_input.php; updated in January 2017). In addition, sequences were compared with known antimicrobial fragments.

\section{RESULTS AND DISCUSSION}

\section{Dromedary LF Purification, Peptic Hydrolysis, and CEC Fractionation of Hydrolysates}

To monitor the purification procedure, an SDS-PAGE analysis of filtrates 1 to 5 obtained at each CEC step was carried out. Analysis of electrophoretic profiles of filtrates 4 and 5 (Figure 1A) revealed only 1 common band with a high molecular weight close to that of LF. To assess the presence of dromedary LF in those filtrates, samples of filtrates 4 and 5 were lyophilized and further analyzed by SDS-PAGE. The calculated molecular mass using molecular weight markers of the unique band was $75 \mathrm{kDa}$ (Figure 1B). Thus, SDS-PAGE profile analysis revealed that the purification procedure using $\mathrm{CEC}$ with high $\mathrm{NaCl}$ concentration for elution allowed the recovery of only 1 band that presented a molecular 
(A)

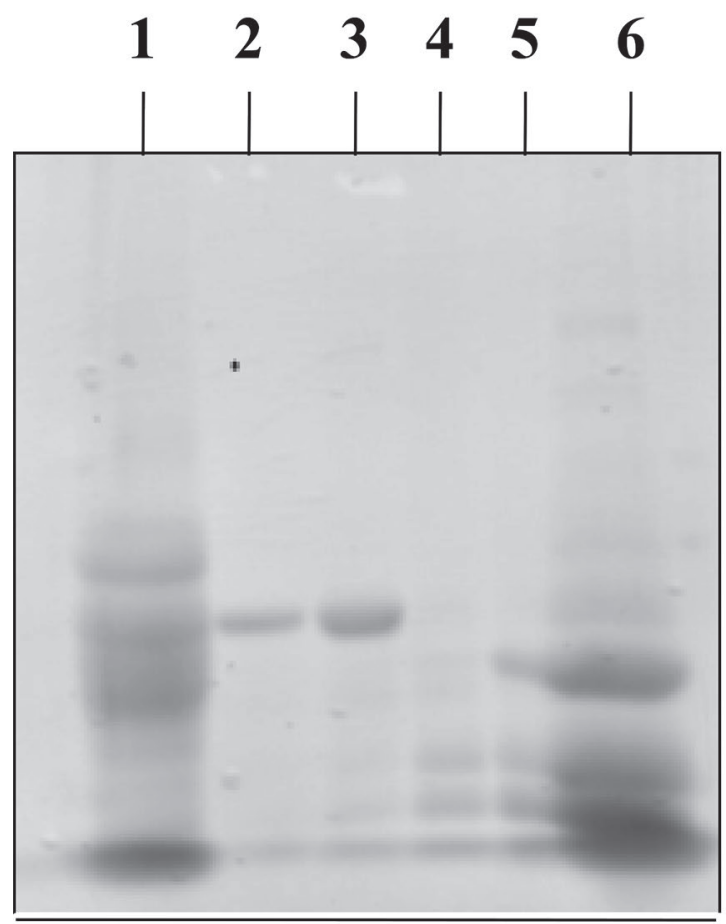

(B)

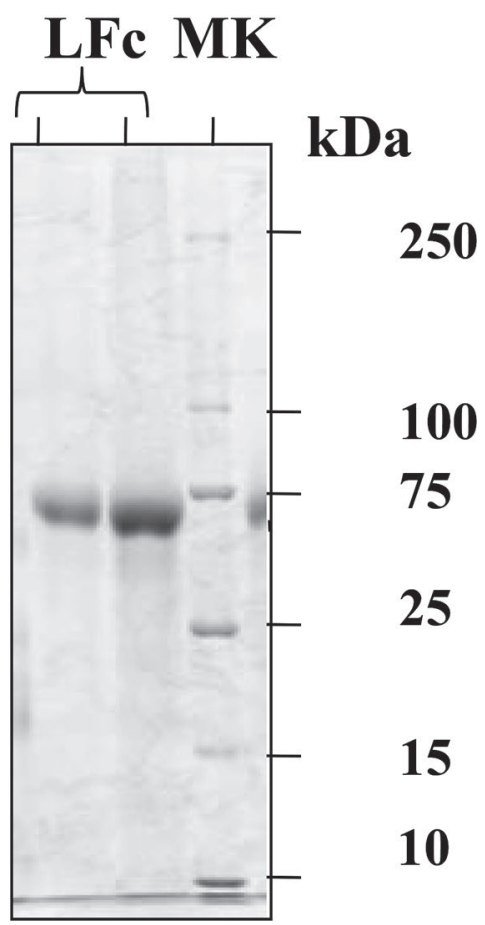

Figure 1. Sodium dodecyl sulfate-PAGE analysis. (A) Dromedary colostrum (10 $\mu \mathrm{L}$; dilution: 1/5; lane 1) and filtrates obtained during lactoferrin purification steps on CM Sepharose Fast Flow gel (Healthcare Life Sciences, Vélizy-Villacoublay, France) in a batch procedure (40 $\mu \mathrm{L}$ ). Lanes 2, 3, 4, 5, and 6 were filtrate 5, 4, 3, 2, and 1, respectively. (B) Dromedary lactoferrin solution (LFc) obtained after resuspension of lyophilized powder of filtrates 4 and $5(1 \mathrm{mg} / \mathrm{mL}$; left lane $=10 \mu \mathrm{L}$; right lane $=20 \mu \mathrm{L})$. MK $=$ molecular weight markers purchased from Bio-Rad (Precision Protein Plus Standards, $5 \mu \mathrm{L}$; Marnes La Coquette, France).

weight $(75 \mathrm{kDa})$ consistent with the theoretical value of dromedary LF molecular weight $(75.25 \mathrm{kDa}$; Kappeler, 1998). This result is confirmed by MS analysis, which showed that all identified peptides were derived only from LF protein (Supplemental File S1, https:// doi.org/10.3168/jds.2018-15548).

The purification of LF from $1 \mathrm{~L}$ of dromedary colostrum collected 2 and $3 \mathrm{~d}$ after parturition led to the recovery of $0.84 \mathrm{~g}$ of lyophilized powder. Considering that in a previous study El-Hatmi et al. (2007) observed that the concentration of LF (estimated by densitometry after SDS-PAGE electrophoresis) in dromedary colostrum can vary from 0.7 to $2.3 \mathrm{~g} / \mathrm{L}$ during the first $192 \mathrm{~h}$ of lactation and that the maximum level of LF $(2.3 \mathrm{~g} / \mathrm{L})$ was reached $48 \mathrm{~h}$ after parturition, the purification yield was thus at least $36 \%$ in the present study.

Pure LF was then hydrolyzed by pepsin, and the LF DH calculated after the determination of the free amino group using the TNBS method was $16.8 \pm 2.1 \%$. A comparison was made between the calculated $\mathrm{DH}$ and that calculated by theoretical enzymatic digestion of dromedary LF using the Expasy database (http:/ /us.expasy.org) and using pepsin at $\mathrm{pH} 1.3$ (no data were found on this database for pepsin at $\mathrm{pH}=2$ ). Considering that dromedary LF possesses 137 potential pepsin-specific target sites and 689 AA residues in its primary structure, the calculated theoretical $\mathrm{DH}$ was $19.9 \%$, which is slightly higher than that measured in this study by determination of free $\alpha$-amino groups. Different DH of milk LF were reported in the literature due to the variation of enzyme:substrate ratio, type of milk, and AA sequence of this protein (Yvon et al., 1992; Furlund et al., 2013). Compared with the $\mathrm{DH}$ of the above results, the DH in our study reflects the pepsin broad specificity (hydrolysis of the peptide bonds following Phe, Tyr, Trp, and Leu residues) on dromedary LF.

Fractionation of peptidic fragments from dromedary LF peptic hydrolysate was performed using CEC. Considering $\mathrm{OD}_{280}$ measurements (Figure 2), collected fractions were pooled in 4 fractions (referred to as $\mathbf{d L F c} 1$ to 4$)$. 


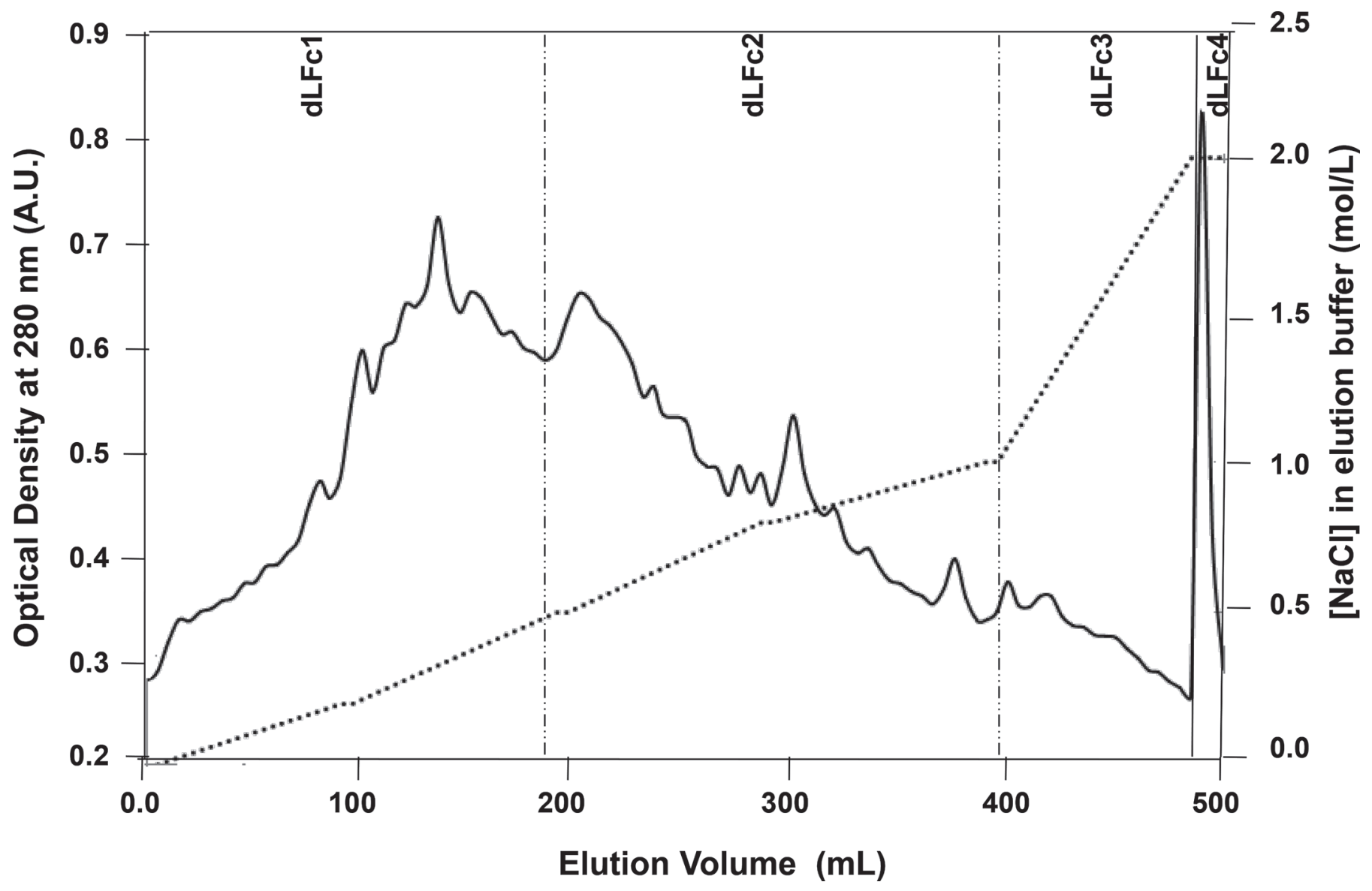

Figure 2. Cation exchange chromatogram on Purolite C106 EP/2156 gel (Paris, France; $10 \mathrm{~mL}$ ) of peptic hydrolysate dromedary lactoferrin (400 mg). Elution was performed at $1 \mathrm{~mL} / \mathrm{min}$ using a sodium phosphate buffer $(50 \mathrm{~m} M, \mathrm{pH} 6.5)$ supplemented with increasing NaCl concentrations (from 0 to $2 M$; dotted line). $\mathrm{dLFc} 1-4=$ fractions of peptic hydrolysates of dromedary lactoferrin.

\section{Antilisterial Activity Determination}

Percentages of L. innocua growth inhibition, calculated after $24 \mathrm{~h}$ of incubation at $30^{\circ} \mathrm{C}$ in the presence of dromedary colostrum, LF, LF peptic hydrolysate, and its fractions are shown in Table 1. No bacterial growth inhibitory activity of native dromedary LF (1 $\mathrm{mg} / \mathrm{mL}$ ) against the 2 tested $L$. innocua strains was detected, although colostrum at the same concentration was active against the $L$. innocua LRGIA 01 strain (27.1\% growth inhibition at $24 \mathrm{~h}$ ). Considering that iron binding capacity of LF can promote its antilisterial activity, a control was performed with an iron-depleted sample (i.e., apolactoferrin) prepared as described by Majka et al. (2013). Iron depletion induced no changes in L. innocua growth (Table 1). In this context, the iron saturation of dromedary LF was also determined. The result showed that the iron concentration and saturation of LFc were $0.2607 \mathrm{mg} / \mathrm{g}$ and $17.5 \%$, respectively. This is in line with another study that reported an iron concentration and saturation for bovine $\mathrm{LF}$ of $0.2508 \mathrm{mg} / \mathrm{g}$ and $17.91 \%$, respectively (Zhang et al., 2018). Gibbons et al. (2015) reported that iron saturation ranges between 15 and $20 \%$ for bovine LF and is around $10 \%$ for human LF. Conesa et al. (2008) is the only study that reported data on dromedary iron saturation. This work studied the thermal stability of different LF (i.e., dromedary and human LF) in their native and iron-saturated forms by differential scanning calorimetry without given iron-saturation levels. Results showed that the native form of camel LF presents 2 peaks, which may indicate a higher degree of iron saturation than that showed by the human protein, which presented just 1 peak in the native form. Several studies demonstrated that antimicrobial activity was reduced upon iron saturation (Yamauchi et al., 1993; Jenssen and Hancock, 2009), which was not the case in this study. Besides iron saturation, other factors may affect the antibacterial activity of LF such as polysaccharide chain composition (Kruzel et al., 2013). 
In a previous work (Jrad et al., 2014), the addition of colostrum proteins at $20 \mathrm{mg} / \mathrm{mL}$ in BHI broth induced a $26.7 \%$ reduction of L. innocua LRGIA 01 growth after $24 \mathrm{~h}$ of incubation at $30^{\circ} \mathrm{C}$. It can thus be concluded that the antilisterial effect of colostrum was lower after protein fractionation. This suggests that anti-Listeria activity of dromedary colostrum was due to either antimicrobial proteins other than LF or a combination of several proteins including LF. Furthermore, although the tested concentration of dromedary LF was similar to the one tested for colostrum $(1 \mathrm{mg} / \mathrm{mL})$, comparison with bovine LF data suggested that the minimal inhibitory concentration of dromedary LF was higher. For instance, the minimal inhibitory concentration of bovine LF against L. monocytogenes strains was found to be in the range of 1.6 to $2 \mathrm{mg} / \mathrm{mL}$ (Tomita et al., 1991; Murdock and Matthews, 2002). However, the literature also highlighted that both L. monocytogenes and $E$. coli growth inhibition by bovine LF depends on several parameters (e.g., medium, pH, temperature, and the presence of cations; Murdock and Matthews, 2002). For Del Olmo et al. (2011), interspecies and strain-to-strain variations in bacterial sensitivity to LF could be attributed to differences in the components of the bacterial outer membrane. Furthermore, Benkerroum et al. (2004) reported that the antibacterial activity of dromedary colostrum toward E. coli and L. monocytogenes depended on bacterial strains and growth medium. In the same way, it has been noted that LF at supraoptimal concentrations had a reduced or null effect because the excess free ligand in the medium may affect the equilibrium of a receptor-ligand interaction, decreasing specific interaction and reducing bactericidal activity (Naidu et al.,1993). Thus, the lack of dromedary LF antilisterial activity could be due to our experimental conditions.
Moreover, peptic hydrolysate of dromedary LF did not exert any antilisterial activity at the tested concentration (i.e., $1 \mathrm{~g} / \mathrm{L}$ ). Thus, these results are different from several studies that have shown that hydrolysates (generated by chymosin or pepsin) of bovine LF exhibited a higher antimicrobial activity than those of native bovine LF against various bacteria such as $E$. coli O157:H7 and L361, Salmonella Stanley, Staph. aureus, and L. monocytogenes (Hoek et al., 1997; Shin et al., 1998; Murdock and Matthews, 2002; Ripolles et al., 2015). This might be due to the differences in the primary sequence of dromedary and bovine LF. Furthermore, Saito et al. (1991) observed a relationship between the growing inhibitory effect of bacteria and the DH (performed by heat treatment at acidic $\mathrm{pH}$ ) of bovine LF; more precisely, the optimal $\mathrm{DH}$ of hydrolysates with the highest antibacterial activity was $10 \%$. Thus, our conditions led to a superior DH level (16.8\%), which could have minimized the growth inhibitory effect of total hydrolysate. However, some fractions of peptic hydrolysate of LFc, although tested at only $0.5 \mathrm{~g} / \mathrm{L}$ concentration, significantly $(P<$ 0.001) inhibited the growth of both L. innocua strains, suggesting that some antagonistic peptides could be present in the hydrolysate. More precisely, 3 of the 4 fractions of the dromedary LF peptic hydrolysate (recovered after CEC separation) exhibited antibacterial activity at least against the $L$. innocua LRGIA 01 strain. Furthermore, the dLFc2 and dLFc4 pooled fractions were active against both $L$. innocua strains tested (about $20 \%$ inhibition of growth of L. innocua ATCC 33090 and LRGIA 01 strains after $24 \mathrm{~h}$ of incubation at $\left.30^{\circ} \mathrm{C}\right)$, whereas dLFc1 was active only against the $L$. innocua LRGIA 01 strain (23.5\% inhibition of growth). This result showed that L. innocua ATCC 33090 growth inhibition was less variable and

Table 1. Antibacterial activity of dromedary colostrum, dromedary lactoferrin (LFc), peptic hydrolysates of dromedary lactoferrin (dLFc), and fractions of peptic hydrolysates of dromedary lactoferrin ( $\mathrm{dLFc} 1$ to $\mathrm{dLF} 4$ ) determined after $24 \mathrm{~h}$ of incubation at $30^{\circ} \mathrm{C}$ in brain-heart infusion broth with 2 Listeria innocua strains $^{1}$

\begin{tabular}{|c|c|c|c|c|c|}
\hline Sample & $\begin{array}{l}\text { Tested concentration } \\
\qquad(\mathrm{mg} / \mathrm{mL})\end{array}$ & \multicolumn{2}{|c|}{ L. innocua ATCC 33090} & \multicolumn{2}{|c|}{ L. innocua LRGIA 01} \\
\hline Apo-LFc & 1 & $<10$ & 0.278 & $<10$ & 0.6 \\
\hline $\mathrm{dLFc}$ & 1 & $<10$ & $<0.001$ & $<10$ & $<0.001$ \\
\hline dLFc1 & 0.5 & $<10$ & 0.004 & $23.5 \pm 2.5$ & $<0.001$ \\
\hline dLFc4 & 0.5 & $18.2 \pm 3.6$ & $<0.001$ & $28.4 \pm 5.6$ & 0.005 \\
\hline
\end{tabular}

${ }^{1}$ Antimicrobial activity was estimated by measuring the percentage of inhibition of each bacterial strain growth in the presence of dromedary colostrum, lactoferrin, lactoferrin peptic hydrolysate, and its cation exchange chromatography fractions; $\mathrm{n}=3$. Apo-LFc = iron-depleted lactoferrin. 
that digested dromedary LF activity was dependent on the Listeria strain used.

\section{Nano-Electrospray lonization Tandem MS Coupled with Liquid Chromatograpy and Peptide Antimicrobial Potential Analysis}

The peptide profiles of $\mathrm{dLFc} 2$ and $\mathrm{dLF} 44$ pooled fractions were investigated by tandem mass spectroscopy analysis. Data analysis revealed that dLFc2 and dLFc4 contained 217 and 79 peptides, respectively (Supplemental File S1, https://doi.org/10.3168/jds .2018-15548). Among these peptides, 69 peptides were present in the 2 fractions. Their alignment with the sequence of dromedary LF showed that about $89 \%$ of the LF sequence was covered and thus that it was extensively hydrolyzed by pepsin. Only 4 zones of LF were not hydrolyzed by pepsin into peptides identified in dLFc2 and dLFc4 CEC fractions: the $\mathrm{f}(228-242)$, $\mathrm{f}(309-317)$, and $\mathrm{f}(569-595)$ zones and N-terminal extremity, f(1-48), of LFc primary sequence (Figure 3).
Comparison with the AMP data bank from the University of Nebraska (http://aps.unmc.edu/AP/ database/query_input.php) revealed that 9 identified peptides (6 from dLFc2 and 3 from dLFc4 samples; Table 2) had at least $50 \%$ similarity with 10 known AMP. Among these peptides, 2 identified fragments in fraction dLFc2 (QLFGSPAGQKDL and GSPAGQKDLL) and 1 in fraction dLFc4 (FKDSALGL) are uncharged, have isoelectric points close to 7, and have molecular masses of 1,260, 985, and $849 \mathrm{Da}$, respectively. These peptides do not have common characteristics with the classical antibacterial peptides (Powers and Hancock, 2003); they are neutral peptides with a small proportion of hydrophobic residues. In the same way, the sequence VLKGEADAL corresponds to fragment 384-392 derived from dLFc2 containing glutamic and aspartic acids, is acidic, and has a distinctly negative charge at neutral $\mathrm{pH}$.

Three other sequences corresponding to LDCVHRPVKGY (fragment 423-433), WAKDLKL (fragment 560-566), and RIDKVAHL (fragment 600-607)

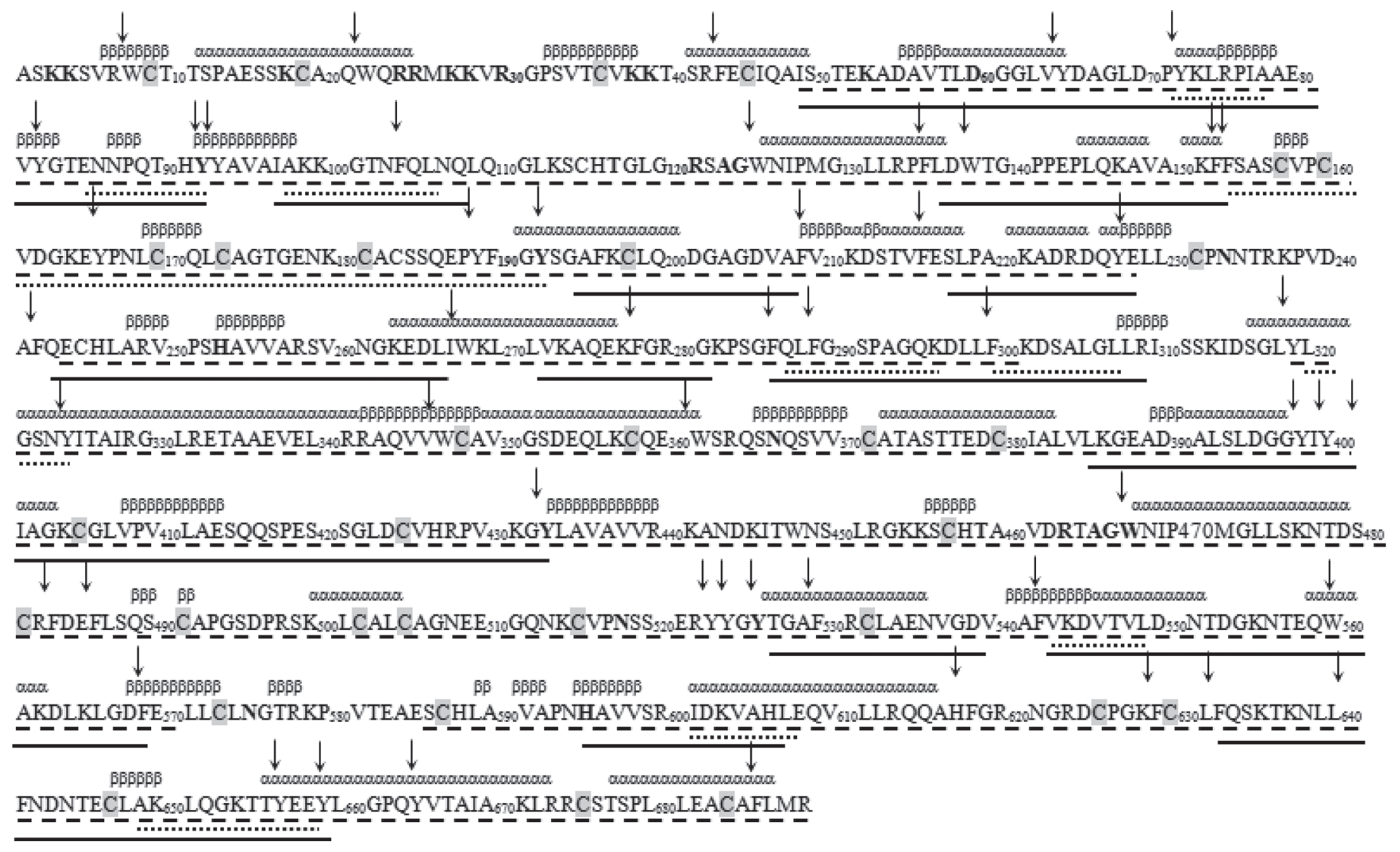

Figure 3. Primary sequence of dromedary lactoferrin recovered in dLFc2 (dashed line) and dLFc4 (dotted line) and identified using tandem MS. Solid black line represents sequences that were identified in both samples. Arrows indicate pepsin potential cleavage sites, bold characters correspond to functional residues, and $\alpha$ and $\beta$ indicate AA involved in $\alpha$-helix and $\beta$-sheet, respectively. Dromedary lactoferrin sequence from Kappeler et al. (1999). dLFc 2 and $4=$ fractions of peptic hydrolysates of dromedary lactoferrin. 
JRAD ET AL.

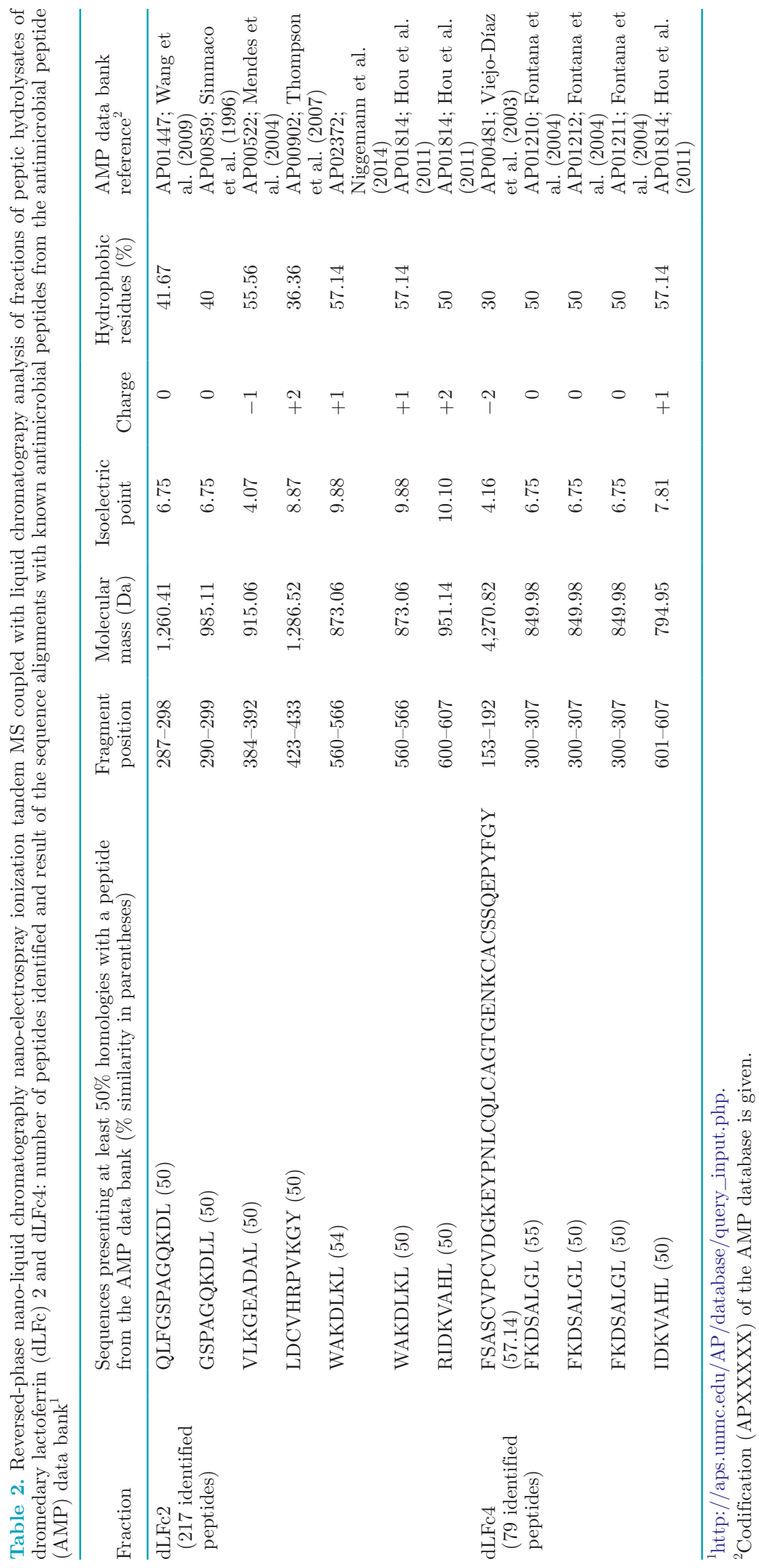


derived from $\mathrm{dLF} 2$, and 1 from dLFc4, IDKVAL (fragment 601-607), are cationic peptides. These peptides are positively charged $(1+$ or $2+$ owing to the presence of basic AA residues), and more than $50 \%$ of their AA sequences comprise hydrophobic residues, which is the case of the majority of AMP. In fact, AMP have alternating hydrophobic and cationic portions. Binding of the cationic part of AMP to the polar heads of negatively charged membrane phospholipids of target microbial cells is necessary for their activity. The hydrophobic parts of most AMP then facilitate their insertion into the bacteria and cause their cell lysis (Hancock and Scott, 2000). Thus, these cationic peptides could possibly contribute to the antilisterial activity of dLFc2. An extended comparison with known AMP revealed that neutral peptides derived from $\mathrm{dLFc} 2$ presented $50 \%$ similarity with known AMP isolated from the skin of frogs, namely temperan-LT1 (AP01447; Wang et al., 2009) and temporin-H (AP00859; Simmaco et al., 1996), which were reported to be active only against gram-positive bacteria. However, the similarity between the neutral peptide FKDSALGL found in dLFc4 and the Jelleine I is $55 \%$ and between Jelleine II and III is $50 \%$. The Jelleines I, II, and III are peptides from 8 to 9 AA residues; for example, they exclusively presented antimicrobial activities against yeast and gram-positive and gram-negative bacteria (Fontana et al., 2004). Additionally, the anionic peptide VLKGEADAL identified in fraction $\mathrm{dLFc} 2$ showed $55 \%$ similarity with a peptide isolated from the venom of the neotropical social wasp Agelai apallipes pallipes named Agelaia-MP. This peptide was characterized as a hemolytic mast cell degranulator toxin presenting a poor antimicrobial action (Mendes et al., 2004). Similarly, 3 cationic peptides ( 2 from $\mathrm{dLFc} 2$ and 1 from $\mathrm{dLFc} 4$ ) revealed similarities with antimicrobial sequences, namely hyposin-H1, isolated from the skin secretion of a frog (Thompson et al., 2007), and PG La-H, isolated from the skin of the African clawed frog (Hou et al., 2011). Both of these peptides are active against gram-positive and gramnegative bacteria. However, the sequence WAKDLKL has both $50 \%$ similarity with the peptide PG La-H and $54 \%$ homology with baceridin, an anti-tumoral plantassociated Bacillus strain peptide (AP02372; Niggemann et al., 2014) that induces apoptosis in tumor cells by a p53-independent pathway. In fact, some studies have shown that some of the cationic AMP, which are toxic to bacteria but not to normal mammalian cells, exhibit a broad spectrum of cytotoxic activity against cancer cells (Hoskin and Ramamoorthy, 2008).

The ninth antimicrobial putative peptide identified within the AMP database, a peptide isolated in the dLFc4 sample, F $_{152}$ SASCVPCVDGKEYPNLCQLCAGTGENKCACSSQEPYFGY ${ }_{192}$, exhibited some homology (54\%) with a fragment from human LF named kaliocin-1 (AP00481). However, this peptide contained in the dLFc4 fraction was longer than kaliocin-1, notably due to 9 supplementary AA in its C terminal extremity (Figure 4). Considering the 31 AA, which are included in the common sequence of these 2 peptides, 24 are similar (i.e., $77 \%$ identity). Kaliocin-1 is a synthetic peptide derived from human LF (ViejoDíaz et al., 2005) that exhibits an anti-Candida activity and an antibacterial effect against $E$. coli ML-35 strain acting on bacterial cytoplasmic membrane (involving $\mathrm{K}^{+}$efflux). As discussed above, the other peptides that presented at least 50\% homology with an AMP from the AMP database were isolated from honeybees, frogs, or amphibian-related species, suggesting that antilisterial activity of the dFLc4 fraction could be partially attributed to the $\mathrm{F}_{152} \mathrm{SASCVPCVDGKEYPNLCQL-}$ CAGTGENKCACSSQEPYFGY 192 peptide because

\section{dLFc4 FSASCVPCVDGKEYPNLCQLCAGTGENKCACSSQEPYFGY}

kaliocin FFSASCVPGADKGQFPNLCRLCAGTGENKCA

\section{dLFc2 LVKAQEKFGRGKPS \\ lactoferrampinB WKLLSKAQEKFGKNKSR}

Figure 4. Comparison of lactoferrampin (van der Kraan et al., 2004) and kaliocin-1 (Viejo-Díaz et al., 2003) sequences with their potential analogs in $\mathrm{dLF} 22$ and $\mathrm{dLFc} 4$ fractions, respectively. dLFc 2 and $4=$ fractions of peptic hydrolysates of dromedary lactoferrin. 
dromedary LF shared $74 \%$ sequence identity and $91 \%$ sequence homology with human LF (Kappeler, 1998; Kappeler et al., 1999).

To date, identified AMP obtained by enzymatic hydrolysis of bovine LF were released from the N-terminal zone of the parent protein. Among antibacterial peptides obtained from bovine LF hydrolysates, only 2 of them, lactoferricin and lactoferrampin, have been studied in detail. The 17-41 fragment of bovine LF (b LF f 17-41), named lactoferricin B, is a cationic and an amphipathic peptide with a molecular weight of 3,125 $\mathrm{Da}$ and is more effective in the inhibition of bacterial growth than undigested LF (Wakabayashi et al., 2003). As we did not isolate peptides from the N-terminal extremity $\mathrm{f}(1-48)$ of cameline LF, the observed antimicrobial activity of $\mathrm{dLFc} 2$ and $\mathrm{dLFc} 4$ fractions could not be attributed to an equivalent of lactoferricin B. The second well-known AMP generated from bovine $\mathrm{LF}$ is lactoferrampin $\mathrm{B}$, corresponding to the 268-284 fragment (b LF f 268-284) in the N-terminal domain of bovine LF. This AMP exhibits broad antimicrobial action against Bacillus subtilis, E. coli, P. aeruginosa, and Staph. aureus (van der Kraan et al., 2004). One peptide identified in the $\mathrm{dLFc} 2$ fraction, more precisely the LVKAQEKFGRGKPS fragment (dromedary LF f 271-284), can be considered a dromedary equivalent of a lactoferrampin B (LF0149, milk AMP database). Although this peptide contains 3 fewer AA, comparison of the 2 sequences (Figure 4) shows that these 2 peptides shared 5 positively charged residues (Lys) and hydrophobic domains. The lack of the tryptophan residue at the N-extremity of the dLFc2 fragment $\left(\operatorname{Trp}_{268}\right.$ in lactoferrampin) can be balanced by the presence of the hydrophobic residue $\mathrm{Val}_{272}$ instead of $\mathrm{Ser}_{272}$. As explained above, these 2 features (i.e., the presence of positively charged residues as well as a hydrophobic domain) characterize cationic AMP, and it has been shown that the removal of $\operatorname{Trp}_{268}$ and $\mathrm{Lys}_{269}$ in lactoferrampin leads to a decrease in its antimicrobial activity (van der Kraan et al., 2005).

\section{CONCLUSIONS}

Antimicrobial activity assays performed on 2 L. innocua strains showed that the observed antilisterial activity of dromedary colostrum could not be attributed to LF. Complementary studies that focused on dromedary LF instead of hydrolyzed fractions of this protein should allow researchers to determine the influence of experimental design and of interspecies and strain-tostrain variations in bacterial sensitivity on dromedary LF as already reported by other authors for bovine LF. However, our data pointed out that 2 fractions of the dromedary LF peptic hydrolysate obtained using CEC exhibit an antilisterial activity. Among peptides generated by pepsin, MS data analysis revealed that each fraction contained a specific peptide presenting some homologies with synthetic AMP derived from human (kaliocin-1) or bovine (lactoferrampin B) LF. In addition, these fractions contained some peptides presenting at least 50\% homology with known AMP previously isolated from honeybees, frogs, or amphibians, which can also contribute to the antibacterial activity of tested fractions (synergistic effects). Further experiments, including peptide purification or synthesis, should now be performed to check whether the observed antilisterial activity was due to these peptides. It could also be interesting to determine the minimal concentration necessary to inhibit Listeria growth and the optimal sequence that allows the highest activity. This work has pointed out that hydrolysis of dromedary LF by pepsin generated anti-Listeria peptides. To date, no results concerning the antilisterial activity of kaliocin-1 or lactoferrampin B have been found. As a perspective, it could be interesting to compare antimicrobial activity spectra (against various Listeria, E. coli, and Candida strains) and the minimal inhibitory concentration of synthetic kaliocin-1, lactoferrampin, and their putative dromedary counterparts.

\section{ACKNOWLEDGMENTS}

The authors thank Awatef Boubakri (The Higher Institute of Applied Studies in Humanities at Medenine, University of Gabes, Gabes, Tunisia) for his kind help with the English in this article. We thank the French Ministry of Foreign Affairs (Bourg en Bresse, France) for supporting Halima El Hatmi's stay (SSHN "Séjours Scientifiques de Haut Niveau" grants) in the BioDyMIA (Bioingénierie et Dynamique Microbienne aux Interfaces Alimentaires) laboratory (Bourg en Bresse, France). The authors also thank the MERS (Ministère de l'Enseignement Supérieur et de la Recherche Scientifique), Arid Land Institute (Medenine, Tunisia), and the University of Gabes for supporting Zeineb Jrad's stays in BioDyMIA laboratory.

\section{REFERENCES}

Aygun, O., and S. Pehlivanlar. 2006. Listeria spp. in the raw milk and dairy products in Antakya, Turkey. Food Control 17:676-679.

Bellamy, W., M. Takase, K. Yamauchi, H. Wakabayashi, K. Kawase, and M. Tomita. 1992. Identification of the bactericidal domain of lactoferrin. Biochim. Biophys. Acta 1121:130-136.

Benkerroum, N., B. Makkaoui, N. Bennani, and H. Kamal. 2004. Antimicrobial activity of camel's milk against pathogenic strains of Escherichia coli and Listeria monocytogenes. Int. J. Dairy Technol. 57:39-43.

Bernini, V., E. Dalzini, C. Lazzi, B. Bottari, S. Bisotti, M. Fontana, and E. Neviani. 2015. A multi-sampling approach to evaluate an infrared surface treatment for reducing Listeria monocytogenes 
contamination on whole Gorgonzola cheese rinds. Food Control $55: 75-81$.

Chan, J. C. K., and E. C. Y. Li-Chan. 2007. Production of lactoferricin and other cationic peptides from food grade bovine lactoferrin with various iron saturation levels. J. Agric. Food Chem. 55:493-501.

Conesa, C., L. Sánchez, C. Rota, M. D. Pérez, M. Calvo, S. Farnaud, and R. W. Evans. 2008. Isolation of lactoferrin from milk of different species: Calorimetric and antimicrobial studies. Comp. Biochem. Physiol. B 150:131-139.

Del Olmo, A., J. Calzada, and M. Nunez. 2011. Antimicrobial efficacy of lactoferrin, its aminated and pepsin-digested derivatives, and their combinations, on Escherichia coli O157:H7 and Serratia liquefaciens. Lett. Appl. Microbiol. 52:9-14.

den Bakker, H. C., C. A. Cummings, V. Ferreira, P. Vatta, R. H. Orsi, L. Degoricija, M. Barker, O. Petrauskene, M. R. Furtado, and M. Wiedmann. 2010. Comparative genomics of the bacterial genus Listeria: Genome evolution is characterized by limited gene acquisition and limited gene loss. BMC Genomics 11:688.

El-Hatmi, H., J.-M. Girardet, J.-L. Gaillard, M. H. Yahyaoui, and H. Attia. 2007. Characterisation of whey proteins of camel (Camelus dromedarius) milk and colostrum. Small Rumin. Res. 70:267-271.

El-Hatmi, H., A. Levieux, and D. Levieux. 2006. Camel (Camelus dromedarius) immunoglobulin G, $\alpha$-lactalbumin, serum albumin and lactoferrin in colostrum and milk during the early post partum period. J. Dairy Res. 73:288-293.

Fontana, R., M. A. Mendes, B. M. de Souza, K. Konno, L. M. César, O. Malaspina, and M. S. Palma. 2004. Jelleines: A family of antimicrobial peptides from the royal jelly of honeybees (Apismellifera). Peptides 25:919-928.

Furlund, C. B., E. K. Ulleberg, T. G. Devold, R. Flengsrud, M. Jacobsen, C. Sekse, H. Holm, and G. E. Vegarud. 2013. Identification of lactoferrin peptides generated by digestion with human gastrointestinal enzymes. J. Dairy Sci. 96:75-88.

Gibbons, J. A., J. R. Kanwar, and R. K. Kanwar. 2015. Iron-free and iron-saturated bovine lactoferrin inhibit survivin expression and differentially modulate apoptosis in breast cancer. BMC Cancer 15:425-440.

Habib, H. M., W. H. Ibrahim, R. Schneider-Stock, and H. M. Hassan. 2013. Camel milk lactoferrin reduces the proliferation of colorectal cancer cells and exerts antioxidant and DNA damage inhibitory activities. Food Chem. 141:148-152.

Hammer, P., W. Bockelmann, and W. Hoffmann. 2017. Fate of Listeria innocua during production and ripening of smeared hard cheese made from raw milk. J. Dairy Sci. 100:7846-7856.

Hancock, R. E., and M. G. Scott. 2000. The role of antimicrobial peptides in animal defenses. Proc. Natl. Acad. Sci. USA 97:8856-8861.

Hoek, K. S., J. M. Milne, P. A. Grieve, D. A. Dionysius, and R. Smith. 1997. Antibacterial activity in bovine lactoferrin-derived peptides. Antimicrob. Agents Chemother. 41:54-59.

Hoskin, D. W., and A. Ramamoorthy. 2008. Studies on anticancer activities of antimicrobial peptides. Biochim. Biophys. Acta 1778:357-375.

Hou, F., J. Li, P. Pan, J. Xu, L. Liu, W. Liu, B. Song, N. Li, J. Wan, and H. Gao. 2011. Isolation and characterisation of a new antimicrobial peptide from the skin of Xenopus laevis. Int. J. Antimicrob. Agents 38:510-515.

Iglesias-Figueroa, B. F., E. A. Espinoza-Sánchez, T. S. SiqueirosCendón, and Q. Rascón-Cruz. 2019. Lactoferrin as a nutraceutical protein from milk, an overview. Int. Dairy J. 89:37-41.

Ismael, A. B., S. M. Abd El Hafez, M. B. Mahmoud, A. A. Elaraby, and H. M. Hassan. 2013. Development of new strategy for non-antibiotic therapy: Dromedary camel lactoferrin has a potent antimicrobial and immunomodulator effects. Adv. Infect. Dis. 3:231-237.

Jenssen, H., and R. E. W. Hancock. 2009. Antimicrobial properties of lactoferrin. Biochimie 91:19-29.

Jrad, Z., H. El-Hatmi, I. Adt, J. M. Girardet, C. Cakir-Kiefer, J. Jardin, P. Degreave, T. Khorchani, and N. Oulahal. 2014. Effect of digestive enzymes on antimicrobial, radical scavenging and angiotensin I-converting enzyme inhibitory activities of camel colostrum and milk proteins. Dairy Sci. Technol. 94:205-224.
Kappeler, S. R. 1998. Compositional and structural analysis of camel milk proteins with emphasis on protective proteins. $\mathrm{PhD}$ Thesis. Zurich Univ., Zurich, Switzerland.

Kappeler, S. R., M. Ackermann, Z. Farah, and Z. Puhan. 1999. Sequence analysis of camel (Camelus dromedarius) lactoferrin. Int. Dairy J. 9:481-486.

Konuspayeva, G., B. Faye, G. Loiseau, and D. Levieux. 2007. Lactoferrin and immunoglobulin contents in camel's milk (Camelus bacterianus, Camelus dromedarius and hybrids) from Kazakhstan. J. Dairy Sci. 90:38-46.

Kruzel, M. L., J. K. Actor, M. Zimecki, J. Wise, P. Płoszaj, S. Mirza, M. Kruzel, S.-A. Hwang, X. Ba, and I. Boldogh. 2013. Novel recombinant human lactoferrin: Differential activation of oxidative stress related gene expression. J. Biotechnol. 168:666-675.

Laemmli, U. K. 1970. Cleavage of structural proteins during the assembly of the head of bacteriophage T4. Nature 227:680-685.

Langella, O., B. Valot, T. Balliau, M. Blein-Nicolas, L. Bonhomme, and M. Zivy. 2017. X!Tandem Pipeline: A tool to manage sequence redundancy for protein inference and phosphosite identification. J. Proteome Res. 16:494-503.

Majka, G., K. Śpiewak, K. Kurpiewska, P. Heczko, G. Stochel, M. Strus, and M. Brindell. 2013. A high-throughput method for the quantification of iron saturation in lactoferrin preparations. Anal Bioanal. Chem. 405:5191-5200.

Mariani, C., R. Briandet, J. F. Chamba, E. Notz, A. Carnet-Pantiez, R. N. Eyoug, and N. Oulahal. 2007. Biofilm ecology of wooden shelves used in ripening the French, raw milk, smear cheese, Reblochon de Savoie. J. Dairy Sci. 90:1653-1661.

McKellar, R. C. 1981. Development of off-flavour in ultra-high temperature and pasteurised milk as a function of proteolysis. J. Dairy Sci. 64:2138-2145.

Mendes, M. A., B. M. de Souza, M. R. Marques, and M. S. Palma. 2004. Structural and biological characterization of two novel peptides from the venom of the neotropical social wasp Agelai apallipes pallipes. Toxicon 44:67-74.

Mohanty, D. P., S. Mohapatra, S. Misra, and P. S. Sahu. 2016. Milk derived bioactive peptides and their impact on human health-A review. Saudi J. Biol. Sci. 23:577-583.

Morandi, S., M. Brasca, R. Lodi, and G. Battelli. 2009. Inactivation by ozone of Listeria monocytogenes on cheese. Sci. Tec. Latt.-Casearia 60:211-215.

Murdock, C. A., and K. R. Matthews. 2002. Antibacterial activity of pepsin-digested lactoferrin on foodborne pathogens in buffered broth systems and ultra-high temperature milk with EDTA. J. Appl. Microbiol. 93:850-856.

Naidu, S. S., U. Svensson, A. Kishore, and A. S. Naidu. 1993. Relationship between antibacterial activity and porin binding of lactoferrin in Escherichia coli and Salmonella typhimurium. Antimicrob. Agents Chemother. 37:240-245.

Niggemann, J., P. Bozko, N. Bruns, A. Wodtke, M. T. Gieseler, K. Thomas, C. Jahns, M. Nimtz, I. Reupke, T. Bruser, G. Auling, N. Malek, and M. Kalesse. 2014. Baceridin, a cyclic hexapeptide from an epiphytic Bacillus strain, inhibits the proteasome. ChemBioChem 15:1021-1029.

Plate, K., S. Beutel, H. Buchholz, W. Demmer, S. Fisher-Frühholz, O. Reif, R. Ulber, and T. Scheper. 2006. Isolation of bovine lactoferrin, lactoperoxidase and enzymatically prepared lactoferricin from proteolytic digestion of bovine lactoferrin using adsorptive membrane chromatography. J. Chromatogr. A 1117:81-86.

Powers, J. P. S., and R. E. W. Hancock. 2003. The relationship between peptide structure and bacterial activity. Peptides 24:1681-1691.

Redwan, E. M., N. A. El-Baky, A. M. Al-Hejin, M. N. Baeshen, H. A. Almehdar, A. Elsaway, A. B. Gomaa, S. B. Al-Masaudi, F. A. Al-Fassi, I. E. AbuZeid, and V. N. Uversky. 2016. Significant antibacterial activity and synergistic effects of camel lactoferrin with antibiotics against methicillin-resistant Staphylococcus aureus (MRSA). Res. Microbiol. 167:480-491.

Ripolles, D., S. Harouna, J. A. Parron, M. Cavlo, M. D. Perez, J. J. Carraminna, and L. Sanchez. 2015. Antibacterial activity of bovine milk lactoferrin and its hydrolysate prepared with pepsin, 
chymosin and microbial rennet against foodborne pathogen, Listeria monocytogenes. Int. Dairy J. 45:15-22.

Saito, H., H. Miyakawa, Y. Tamura, S. Shimamura, and M. Tomita. 1991. Potent bactericidal activity of bovine lactoferrin hydrolysate produced by heat treatment at acidic pH. J. Dairy Sci. 74:37243730.

Shi, P., M. Liu, F. Fan, H. Chen, C. Yu, W. Lu, and M. Du. 2018. Identification and mechanism of peptides with activity promoting osteoblast proliferation from bovine lactoferrin. Food Biosci. $22: 19-25$

Shin, K., K. Yamauchi, S. Teraguchi, H. Hayasawa, M. Tomita, Y. Otsuka, and S. Yamazaki. 1998. Antibacterial activity of bovine lactoferrin and its peptides against enterohaemorrhagic Escherichia coli O157:H7. Lett. Appl. Microbiol. 26:407-411.

Simmaco, M., G. Mignogna, S. Canofeni, R. Miele, M. L. Mangoni, and D. Barra. 1996. Temporins, antimicrobial peptides from the European red frog Rana temporaria. Eur. J. Biochem. 242:788-792.

Thompson, A. H., A. J. Bjourson, D. F. Orr, C. Shaw, and S. McClean. 2007. Amphibian skin secretomics: Application of parallel quadrupole time-of-flight mass spectrometry and peptide precursor cDNA cloning to rapidly characterize the skin secretory peptidome of Phyllomedusa hypochondrialis azurea: Discovery of a novel peptide family, the hyposins. J. Proteome Res. 6:3604-3613.

Tomita, M., W. Bellamy, M. Takase, K. Yamauchi, H. Wakabayashi, and K. Kavase. 1991. Potent antibacterial peptides generated by pepsin digestion of bovine lactoferrin. J. Dairy Sci. 74:4137-4142.

Tsuda, H., T. Kozu, G. Iinuma, Y. Ohashi, Y. Saito, D. Saito, T. Akasu, D. B. Alexander, M. Futakuchi, K. Fukamachi, J. Xu, T. Kakizoa, and M. Ligo. 2010. Cancer prevention by bovine lactoferrin: From animal studies to human trial. Biometals 23:399-409.

van der Kraan, M. I. A., J. Groenink, K. Nazmi, E. C. I. Veerman, J. G. M. Bolscher, and A. V. N. Amerongen. 2004. Lactoferrampin: A novel antimicrobial peptide in the $\mathrm{N}_{1}$-domain of bovine lactoferrin. Peptides 25:177-183.

van der Kraan, M. I. A., K. Nazmi, A. Teeken, J. Groenink, W. van't Hof, E. C. I. Veerman, J. G. M. Bolsher, and A. V. Nieuw Amerongen. 2005. Lactoferrampin, an antimicrobial peptide of bovine lactoferrin, exerts its candidacidal activity by a cluster of positively charged residues at the C-terminus in combination with a helix-facilitating N-terminal part. Biol. Chem. 386:137-142.

van der Strate, B. W., L. Beljaars, G. Molema, M. C. Harmsen, and D. K. Meijer. 2001. Antiviral activities of lactoferrin. Antiviral Res. 52:225-239.
Velliyagounder, K., J. B. Kaplan, D. Furgang, D. Legarda, G. Diamond, R. E. Parkin, and D. H. Fine. 2003. One of two human lactoferrin variants exhibits increased antibacterial and transcriptional activation activities and is associated with localized juvenile periodontitis. Infect. Immun. 71:6141-6147.

Viejo-Díaz, M., M. T. Andrés, and J. F. Fierro. 2005. Different antiCandida activities of two human lactoferrin-derived peptides, Lfpep and kaliocin-1. Antimicrob. Agents Chemother. 49:2583-2588.

Viejo-Díaz, M., M. T. Andrés, J. Pérez-Gil, M. Sánchez, and J. F. Fierro. 2003. Potassium efflux induced by a new lactoferrin-derived peptide mimicking the effect of native human lactoferrin on the bacterial cytoplasmic membrane. Biochemistry (Mosc) 68:217-227.

Wakabayashi, H., M. Takase, and M. Tomita. 2003. Lactoferricin derived from milk protein lactoferrin. Curr. Pharm. Des. 9:12771287.

Wang, H., X. Yan, H. Yu, Y. Hu, Z. Yu, H. Zheng, Z. Chen, Z. Zhang, and J. Liu. 2009. Isolation, characterization and molecular cloning of new antimicrobial peptides belonging to the brevinin-1 and temporin families from the skin of Hylarana latouchii (Anura: Ranidae). Biochimie 91:540-547.

Wen, Y., Q. He, D. Ma, Q. Hou, H. Zhang, and L. Y. Kwork. 2017. An intact gut microbiota may be required for lactoferrin-driven immunomodulation in rats. J. Funct. Foods 39:268-278.

Yamauchi, K., M. Tomita, T. J. Giehl, and R. T. Ellison. 1993. Antibacterial activity of lactoferrin and a pepsin-derived lactoferrin peptide fragment. Infect. Immun. 61:719-728.

Yvon, M., S. Beucher, P. Scanff, S. Thirouin, and J. P. Pelissier. 1992 In vitro simulation of gastric digestion of milk proteins: Comparison between in vitro and in vivo data. J. Agric. Food Chem. 40:239-244

Zhang, J. L., X. Han, Y. J. Shan, L. W. Zhang, M. Du, M. Liu, H. X. Yi, and Y. Ma. 2018. Effect of bovine lactoferrin and human lactoferrin on the proliferative activity of the osteoblast cell line MC3T3-E1 in vitro. J. Dairy Sci. 101:1827-1833.

Zucca, F. A., J. Segura-Aguilar, E. Ferrari, P. Muñoz, I. Paris, D. Sulzer, T. Sarna, L. Casella, and L. Zecca. 2017. Interactions of iron, dopamine and neuromelanin pathways in brain aging and Parkinson's disease. Prog. Neurobiol. 155:96-119. 